\title{
Development of multiplex reverse transcription-polymerase chain reaction for differentiation of strains of infectious bursal disease virus and primary screening of the virus in Thailand
}

\author{
Nataya Charoenvisal(iD \\ Avian Health research Unit, Department of Veterinary Medicine, Faculty of Veterinary Science, \\ Chulalongkorn University, Bangkok 10330, Thailand. \\ Corresponding author: Nataya Charoenvisal, e-mail: nataya.c@chula.ac.th \\ Received: 22-07-2021, Accepted: 28-10-2021, Published online: 14-12-2021
}

doi: www.doi.org/10.14202/vetworld.2021.3105-3110 How to cite this article: Charoenvisal N (2021) Development of multiplex reverse transcription-polymerase chain reaction for differentiation of strains of infectious bursal disease virus and primary screening of the virus in Thailand, Veterinary World, 14(12): 3105-3110.

\begin{abstract}
Background and Aim: A new set of primers (400 base pairs partial of VP2) was designed and used for the infectious bursal disease virus (IBDV) screening test. Using this new primer set, the enzymes $M b o I$ and Bst $N I$ were unable to differentiate the field and vaccine strains. As a result, a new simple, cheap, and appropriate tool for strain differentiation is required. The objective of this study was to develop the appropriate restriction fragment length polymorphism (RFLP) and multiplex reverse transcription-polymerase chain reaction (RT-PCR) for the differentiation of classic IBDV (cIBDV) strains and very virulent IBDV (vvIBDV) strains in Thailand.
\end{abstract}

Materials and Methods: Ninety seven bursa of Fabricius from 16 farms were collected from farms in the eastern and central regions of Thailand. RT-PCR screening showed that 82 samples were positive for IBDV and 15 samples were negative. Then, selected samples were sequenced from each farm with a positive test.

Results: The sequencing results showed that samples from six of the farms were vvIBDV and samples from the other six farms were cIBDV. Although the whole genome sequencing was incomplete, both the sequencing results of segment A and segment B showed high similarity between cIBDV and vvIBDV. Restriction enzyme cutting site and primers for multiplex RT-PCR were hard to design. An RT-PCR-RFLP method was developed, but it failed to differentiate IBDV strains. However, the multiplex RT-PCR was able to differentiate cIBDV from vvIBDV. Four primers were used in the multiplex RT-PCR.

Conclusion: These four primers were used together in one reaction at an annealing temperature of $45^{\circ} \mathrm{C}$. Therefore, multiplex RT-PCR is a less complicated, cheaper, and less time-consuming method for the differentiation of cIBDV and VvIBDV strains.

Keywords: infectious bursal disease virus, multiplex reverse transcription-polymerase chain reaction, restriction fragment length polymorphism, strain, Thailand.

\section{Introduction}

Infectious bursal disease (IBD) or Gumboro disease is a viral infectious disease that results in economic loss to the poultry industry worldwide. The disease is caused by IBD virus (IBDV). In chicken, the virus has a high mortality rate, can decrease production, and cause immunosuppressive effects [1]. IBDV has been of concern in the industry since the 1960s and still affects poultry health in many countries, including Thailand.

The IBDV genome consists of two segments. Segment A, size $3.2 \mathrm{~kb}$, has two overlapping open reading frames (ORFs). The first ORF encodes one non-structural protein, VP5. The second ORF encodes three major structural proteins: VP2, VP3, and VP4. Segment B, size $2.9 \mathrm{~kb}$, encodes the VP1 protein [2].

Copyright: Charoenvisal. Open Access. This article is distributed under the terms of the Creative Commons Attribution 4.0 International License (http://creativecommons.org/licenses/ by/4.0/), which permits unrestricted use, distribution, and reproduction in any medium, provided you give appropriate credit to the original author(s) and the source, provide a link to the Creative Commons license, and indicate if changes were made. The Creative Commons Public Domain Dedication waiver (http:// creativecommons.org/publicdomain/zero/1.0/) applies to the data made available in this article, unless otherwise stated.
As VP2 is the most variable gene, it was chosen to identify IBDV strains [3-5]. IBDV is classified into seven genogroups by the hypervariable region of the VP2 protein. Genogroup 1 is for predominantly classic strains (classic IBD virus [cIBDV]). Genogroup 2 is for predominantly variant strains (vaIBDV). Genogroup 3 is predominantly very virulent IBDV (vvIBDV) strains. Genogroup 4 is for the viruses mostly found in Latin America, Japan, and the United Arab Emirates (UAE). Genogroup 5 is for the viruses found in Mexico and Southeast United States. Genogroup 6 is for viruses found in Saudi Arabia, Italy, and Russia. Genogroup 7 is the V877, found in Australia [6]. In Thailand, cIBDV, which is classified as genogroup 1 and vvIBDV, which is classified as genogroup 3, have been reported [7].

Sequencing and quantitative real-time reverse transcriptase-polymerase chain reaction (qRT-PCR) methods are accurate molecular tools for the identification of IBDV strains [4,5]. However, sequencing is time-consuming and qRT-PCR is expensive. In 1998, the RT-PCR analysis of 734 base pairs of the partial VP2 gene followed by restriction fragment length polymorphism (RFLP) analysis or RT-PCR-RFLP 
was developed to differentiate the field IBDV from vaccine strain. The enzymes $M b o \mathrm{I}$ and BstNI were used to create the RFLP [8]. This method was simple and has been applied in some laboratories in Thailand. Nevertheless, the primer set of 734 base pairs of partial VP2 was not specific to recent Thai IBDV isolates. Consequently, a new set of primers (400 base pairs partial of VP2) was designed and used for the IBDV screening test. Using this new primer set, the enzymes $M b o I$ and $B s t \mathrm{NI}$ were unable to differentiate the field and vaccine strains. As a result, a new simple, cheap, and appropriate tool for strain differentiation is required.

The objective of this study was to develop an appropriate RFLP and multiplex RT-PCR for the differentiation of cIBDV and vvIBDV in Thailand.

\section{Materials and Methods}

\section{Ethical approval}

Bursa of Fabricius was collected during routine services at the farms. However, the biosafety of virus used in this study was approved by Faculty of Veterinary Science Biosafety Committee Chulalongkorn University (protocol number IBC1931001).

\section{Study period and location}

The study was conducted from April 2017 to March 2021 and was conducted in eastern and central parts of Thailand.

\section{Sample collection}

From 16 farms in the eastern and central parts of Thailand, 97 bursa of Fabricius were collected from chickens with suspected IBDV infection. The fresh tissues were kept in an icebox for 1-2 days during shipping to the laboratory. Subsequently, the fresh tissues were stored at $-80^{\circ} \mathrm{C}$ until the investigation.

\section{RT-PCR for IBDV screening}

All samples were screened for IBDV using RT-PCR analysis. First, each bursa of Fabricius, representing one sample, was homogenized. Then, viral RNA was extracted following the commercial test kit protocol (Geneaid Total RNA mini kit [Tissue], Taiwan). All RNA samples were screened by RT-PCR using primers specific for $400 \mathrm{bp}$ of the partial VP2 gene. The forward primer was IBDVP2 F658 (5'-TAC CAATTCTCATCACAGTACCAA-3') and the reverse primer was IBDVP2_R1039 (5'-CGGAGGGCCCCT GGATAGTT-3'). The positive samples were retained

Table-1: Bursa of Fabricius samples collected from farms in Thailand from April 2017 to October 2019.

\begin{tabular}{|c|c|c|c|}
\hline Farm & $\begin{array}{l}\text { No. of total samples (No. } \\
\text { of sequence sample) }\end{array}$ & Bursal lesion & $\begin{array}{l}\text { IBDV screening test (Strain } \\
\text { classification result) }\end{array}$ \\
\hline A & $10(2)$ & $\begin{array}{l}\text { Redness, swelling, inflammation, petechial } \\
\text { hemorrhage, and debris found inside the } \\
\text { bursa }\end{array}$ & $\begin{array}{l}\text { All samples were positive } \\
\text { ( } v \text { VIBDV) }\end{array}$ \\
\hline B & $5(1)$ & $\begin{array}{l}\text { Redness, swelling, inflammation, petechial } \\
\text { hemorrhage, and debris found inside the } \\
\text { bursa }\end{array}$ & $\begin{array}{l}\text { All samples were positive } \\
\text { ( } v \text { VIBDV) }\end{array}$ \\
\hline C & 1 & Swelling & Negative \\
\hline D & 11 & No lesion & All samples were negative \\
\hline $\mathrm{E}$ & 2 & Bursa was smaller than usual & All samples were negative \\
\hline $\mathrm{F}$ & $5(1)$ & $\begin{array}{l}\text { Redness, swelling, inflammation, petechial } \\
\text { hemorrhage, and debris found inside the } \\
\text { bursa }\end{array}$ & $\begin{array}{l}\text { All samples were positive } \\
\text { (cIBDV) }\end{array}$ \\
\hline G & $7(1)$ & $\begin{array}{l}\text { Redness, swelling, inflammation, petechial } \\
\text { hemorrhage, and debris found inside the } \\
\text { bursa }\end{array}$ & $\begin{array}{l}\text { All samples were positive } \\
\text { (cIBDV) }\end{array}$ \\
\hline $\mathrm{H}$ & $7(1)$ & Redness and swelling & $\begin{array}{l}\text { All samples were positive } \\
\text { ( } \mathrm{V} \text { IBDV) }\end{array}$ \\
\hline I & $5(1)$ & $\begin{array}{l}\text { Redness, swelling, inflammation, petechial } \\
\text { hemorrhage, and debris found inside the } \\
\text { bursa }\end{array}$ & $\begin{array}{l}\text { All samples were positive } \\
\text { ( } \text { VVIBDV) }\end{array}$ \\
\hline J & $17(2)$ & $\begin{array}{l}\text { Redness, swelling, inflammation, petechial } \\
\text { hemorrhage, and debris found inside the } \\
\text { bursa }\end{array}$ & $\begin{array}{l}\text { All samples were positive } \\
\text { (cIBDV) }\end{array}$ \\
\hline K & 1 & Redness & Negative \\
\hline L & $10(1)$ & $\begin{array}{l}\text { Redness, swelling, inflammation, petechial } \\
\text { hemorrhage, and debris found inside the } \\
\text { bursa }\end{array}$ & $\begin{array}{l}\text { All samples were positive } \\
\text { ( } v \text { VIBDV) }\end{array}$ \\
\hline M & $2(1)$ & $\begin{array}{l}\text { Samples were already homogenate at the } \\
\text { farm }\end{array}$ & $\begin{array}{l}\text { All samples were positive } \\
\text { (cIBDV) }\end{array}$ \\
\hline N & $2(1)$ & Redness & $\begin{array}{l}\text { All samples were positive } \\
\text { (cIBDV) }\end{array}$ \\
\hline $\mathrm{O}$ & $10(2)$ & Redness & $\begin{array}{l}\text { All samples were positive } \\
\text { ( } \mathrm{V} \text { IBDV) }\end{array}$ \\
\hline$P$ & $2(1)$ & $\begin{array}{l}\text { Redness, swelling, and petechial } \\
\text { hemorrhage }\end{array}$ & $\begin{array}{l}\text { All samples were positive } \\
\text { (CIBDV) }\end{array}$ \\
\hline
\end{tabular}

IBDV=Infectious bursal disease virus, vVIBDV=Very virulent infectious bursal disease virus, cIBDV=Classic infectious bursal disease virus 
throughout the study, whereas the negative samples were discarded or used as a negative control. From all farms tested, 15 positive samples were selected, with at least one sample from each IBDV-positive farm (Table-1). The samples were then sequenced for 400 base pairs (a partial part of the VP2 gene) and were classified.

\section{Development of RFLP for differentiating IBDV strains}

Two vvIBDV and two cIBDV Thai isolates were selected. The isolates were sequenced for $400 \mathrm{bp}$ (a part of the VP2 gene) and classified into each strain in the screening part. The whole-genome sequence of these isolates was analyzed. The whole genome of IBDV is composed of segment A and segment B. Segment A has 3260 base pairs and segment B has 2816 base pairs. The different points in each strain were compared and an appropriate region for RT-PCR-RFLP was designed. Then, the designed RT-PCR-RFLP was tested with these four selected isolates and IBDV vaccine for optimal time, temperature, and ratio of substance until the result was stable and able to identify the right strains.

In brief, PCR products from forward primer IBDVP2_F658 and reverse primer IBDVP2_R1039 (primers for screening test) were used as samples. The PCR products $(11 \mu \mathrm{L})$ were mixed with NEBuffer ${ }^{\mathrm{TM}}$ (BioLab Inc., USA) $2.5 \mu \mathrm{L}$, nuclease-free water $11 \mu \mathrm{L}$, and CviQi enzyme (BioLab Inc.) $0.5 \mu \mathrm{L}$, and then incubated at $25^{\circ} \mathrm{C}$ for $15 \mathrm{~min}$.

\section{Development of multiplex RT-PCR to differentiate IBDV strains}

The set of samples used for the RFLP development part was used again here. The sequences of the selected strains were compared and used to design an appropriate set of primers to differentiate between strains. The primers had to be able to operate in the same PCR condition without matching to any other sequences. The PCR products of each strain had to result in different numbers of DNA base pairs. Then, the designed primers were tested with the four selected isolates and vaccines for the optimal time, temperature, and substance ratio until the results were stable and identification of the strains was achieved.

\section{Sequencing of IBDV}

One or two samples from each farm with a positive result were selected and used for sequence analysis (400 bp of the partial VP2 gene). The sequence analysis was performed using Sanger sequencing technique; the primers are shown in Table- 2 . The sequence results were compared with the reference strains in GenBank using the Maximum Composite Likelihood model [9] conducted by MEGA X [10]. The reference sequences in GenBank included the following: Strain or isolate STC (D00499), Lukert (AY918948), D78 (AF499929), variant E (AF133904), dIBDV (KT336459), Henan (KT884486), HK46 (AF092943), OKYM (D49706), HLJ-0504 (GQ451330), and UPM766/2018 (MT505341).

\section{Results}

\section{Sample collection and RT-PCR for IBDV screening}

Ninety-seven bursal of Fabricius samples were collected from 16 farms in central and eastern parts of Thailand (Table-1). All samples were homogenized, processed to extract RNA, and then screened by 400 bp RT-PCR. The RT-PCR results showed that 82 samples from 12 farms were positive and 15 samples from four farms were negative.

Table-2: Primer designed for whole-genome sequencing.

\begin{tabular}{|c|c|c|c|}
\hline Primer name & Primer sequence $\left(5^{\prime} \rightarrow 3^{\prime}\right)$ & Size & Position \\
\hline IBDV-A-FB1 & GGATACGATCGGTCTGACCCC & 21 & $1-21$ \\
\hline IBDV-A-R246 & GAACTTGTAGTTCCCATTGCTCTG & 24 & $223-246$ \\
\hline IBDV-A-F116 & GGTCAGAGACCTCGACCTACAAT & 23 & $116-138$ \\
\hline IBDV-A_R728 & CCAACGCTGAGACTTGTGATGG & 22 & $707-728$ \\
\hline IBDVP2_F658 & TACCAАTTCTCATCACAGTACCAA & 24 & $658-682$ \\
\hline IBDVP2_R1039 & CGGAGGGCCCCTGGATAGTT & 20 & $1039-1049$ \\
\hline IBDV-A_F976 & TCATGGTCAGCAAGTGGGAGC & 21 & 976-996 \\
\hline IBDV-A-R1499 & GGGAACAATGTGGAGACCACCG & 22 & $1500-1521$ \\
\hline IBDV-A-F1431 & СTCCСCTGAAGATTGCAGGAGC & 22 & 1431-1452 \\
\hline IBDV-A_R1846 & CCСCATCTGGAGCATATCCATA & 22 & $1825-1846$ \\
\hline IBDV-A_F1792 & TCCTTCATACGAACTCTCTCCG & 22 & $1792-1813$ \\
\hline IBDV-A_R2590 & ССTCСАTСTTCTITGAGATCCG & 22 & $2569-2590$ \\
\hline IBDV-A_F2504 & AGCAGGCTACGGAGTGGAGG & 20 & $2505-2524$ \\
\hline IBDV-A_R3137 & TACCAAGGGGACCCGCGAAC & 20 & $3117-3136$ \\
\hline IBDV-B_F01 & GGATACGATGGGTCTGACCCT & 21 & $3-23$ \\
\hline IBDV-B-R520 & CTTCCGGAAGCTGGAGAAATAG & 22 & $520-541$ \\
\hline IBDV-B-F410 & CCATTGGTGACCAAGAGTACTTCC & 24 & $410-433$ \\
\hline IBDV-B_R921 & TाTCTCCTTTGGTGCGACCAAC & 22 & $898-921$ \\
\hline IBDV-B_F875 & CAAGTCATCAAGTGGACTGCCC & 22 & $875-896$ \\
\hline IBDV-B-R1387 & CCGCCTGCATGTGTTGACG & 19 & $1387-1405$ \\
\hline IBDV-B-F1357 & GACCTAGAGAAGGGGGAGGC & 20 & $1357-1376$ \\
\hline IBDV-B-R2344 & CTITGGCCTITACTGCATCTTG & 22 & 2344-2365 \\
\hline IBDV-B-F2286 & CAGGAATGAAGCCGGACTGAGTGG & 24 & $2286-2309$ \\
\hline
\end{tabular}

IBDV =Infectious bursal disease virus 


\section{Sequencing of IBDV}

Of the 12 farms with a positive test, samples from six farms were cIBDV positive and samples from the other six farms were vvIBDV positive. The results showed that from March 2017 to October 2019, both cIBDV and vvIBDV were circulating in Thailand (Table-1). Primers were designed for whole genome sequencing and the sequences of four samples were examined. Samples 1 and 2 were representative samples of cIBDV and were selected from farm $F$ and $\mathrm{G}$, respectively. Samples 3 and 4 were representative samples of vvIBDV and were selected from farm $\mathrm{H}$ and I, respectively.

However, the whole genome sequences were not completed. In segment A, only nucleotide sequences of sample 3 were completed (3260 base pairs); nucleotides 1-245 were incomplete in samples 1 and 2, and nucleotides 1-249 of sample 4 were incomplete. In segment B, 30-500 base pairs of all four samples were randomly incomplete, although the 2816 base pairs were sequenced.

Segment A from samples 1-4 was compared to the reference sequences in GenBank, starting from nucleotide base 250 to 3,169 . The result showed that samples 1 and 2 were $97.01 \%-98.79 \%$, similar to isolate STC, Lukert, and D78, which were representative of cIBDV. These samples were 94.44\%-96.90\% similar to vaIBDV (variant E), dIBDV (genotype 4), and vvIBDV (Henan, HK46, OKYM, HLJ-0504, and UPM766/2018). Samples 3 and 4 were 96.98\%$97.70 \%$ similar to the reference vvIBDV (Henan, HK46, and OKYM) and 98.51\%-99.24\% similar to isolate HLJ-0504 and UPM766/2018 (vvIBDV isolates from China and Malaysia, respectively). Samples 3 and 4 were $94.26 \%-95.15 \%$ similar to the cIBDV, $94.97 \%-94.51 \%$ similar to vaIBDV, and 93.05\%93.09\% similar to dIBDV (genotype 4) (Table-3).

\section{RFLP attempt for differentiating IBDV strains}

Segment A was chosen for the strain differentiation test because it was closer to a full sequence. Moreover, the most highly variable region (the VP2 gene) was located in segment $A$. The restriction enzyme was designed from the 400 base pairs of the VP2 gene (from 658 to 1039) as this part of all four isolates was detectable. The enzyme CviQi, which cuts the nucleotide sequence at 5'---G/TAC---3' and 3'---CAT/G---5', was selected as a restriction enzyme. The cIBDV strain was expected to show a band of 300 base pairs, and the vvIBDV strain was expected to show a band of 400 base pairs.

Therefore, the enzyme was not appropriate as it resulted in a band of 400 base pairs in all samples. Other enzymes restriction sites were used to compare within the 400 base pair sequence, but there was no enzyme that could cut the different parts of the two different strains.

\section{Development of multiplex RT-PCR for differentiating IBDV strains}

Segment A was more variable than segment $\mathrm{B}$, so the primers to differentiate IBDV strains were designed from segment A (Table-4). From this set of primers, the cIBDV samples were expected to show a specific band of 700 base pairs and the vvIBDV samples were expected to show a specific band of 387 base pairs. Other viruses, such as Newcastle disease virus (NDV) and infectious bronchitis virus (IBV), were not expected to show any specific bands in this reaction.

This primer set could be mixed in a single PCR mixture without any binding to other primers in the set; moreover, the primers worked at the same annealing temperature $\left(45^{\circ} \mathrm{C}\right)$. The results showed specific bands for cIBDV at 700 base pairs and for vvIBDV at 500 base pairs, as expected (Figure-1). The IBDV vaccine did not give a positive result when using a set of primers. NDV and IBV could not be detected in this test. Therefore, the materials used in this test can be considered to be specific and sensitive.

\section{Discussion}

IBD is a highly contagious disease in young chickens and causes economic loss in the poultry industry. New technologies are continuing to improve

Table-3: Comparing percent similarity of segment A (nucleotide 250-3169) between samples 1 and 4 and reference sequences from the GenBank.

\begin{tabular}{|c|c|c|c|c|c|c|c|c|c|c|c|c|c|}
\hline Strains & $\begin{array}{c}\text { Sample } \\
1\end{array}$ & $\begin{array}{c}\text { Sample } \\
2\end{array}$ & STC & Lukert & D78 & $\begin{array}{c}\text { Variant } \\
\text { E }\end{array}$ & dIBDV & Henan & HK46 & OKYM & HLJ-0504 & UPM766 & $\underset{3}{\text { Sample }}$ \\
\hline \multicolumn{14}{|l|}{ Sample 1} \\
\hline Sample 2 & 99.83 & & & & & & & & & & & & \\
\hline STC & 98.79 & 98.61 & & & & & & & & & & & \\
\hline Lukert & 97.12 & 97.01 & 96.79 & & & & & & & & & & \\
\hline D78 & 97.87 & 97.77 & 97.66 & 96.75 & & & & & & & & & \\
\hline Variant E & 96.90 & 96.80 & 96.54 & 95.94 & 96.69 & & & & & & & & \\
\hline dIBDV & 95.70 & 95.29 & 95.43 & 94.72 & 95.14 & 94.34 & & & & & & & \\
\hline Henan & 95.41 & 95.30 & 94.95 & 94.08 & 95.07 & 94.51 & 93.05 & & & & & & \\
\hline HK46 & 95.49 & 95.38 & 95.11 & 94.13 & 95.26 & 94.59 & 93.18 & 97.84 & & & & & \\
\hline OKYM & 95.79 & 95.68 & 95.48 & 94.44 & 95.41 & 94.97 & 93.45 & 98.05 & 99.03 & & & & \\
\hline HLJ-0504 & 95.06 & 94.96 & 94.88 & 93.97 & 94.77 & 94.77 & 92.88 & 96.80 & 97.27 & 97.63 & & & \\
\hline UPM766 & 94.47 & 94.44 & 94.35 & 93.39 & 94.12 & 93.59 & 92.23 & 96.21 & 96.48 & 96.84 & 98.40 & & \\
\hline Sample 3 & 95.26 & 95.15 & 95.06 & 94.27 & 95.15 & 94.47 & 93.09 & 97.01 & 97.41 & 97.70 & 99.24 & 98.54 & \\
\hline Sample 4 & 95.23 & 95.11 & 95.06 & 91.30 & 95.14 & 94.51 & 93.05 & 96.98 & 97.38 & 97.67 & 99.20 & 98.51 & 99.97 \\
\hline
\end{tabular}


Table-4: Primers designed for multiplex RT-PCR.

\begin{tabular}{llcc}
\hline $\begin{array}{l}\text { Primer } \\
\text { name }\end{array}$ & Primer sequence $\left(\mathbf{5}^{\prime} \boldsymbol{\rightarrow} \mathbf{3}^{\prime}\right)$ & Size & Position \\
\hline MPC-F1 & TTACAACTACTGCAGGCTAGTG & 22 & $415-436$ \\
MPC-R1 & CGACCACGACATCTGATCC & 19 & $1096-1114$ \\
MPVV-F1 & TTAAACGGAACCATAAACG & 19 & $488-511$ \\
MPVVR1 & CACAAGTTCTCCCCCGAT & 18 & $854-875$ \\
\hline
\end{tabular}

RT-PCR $=$ Reverse transcription polymerase chain reaction

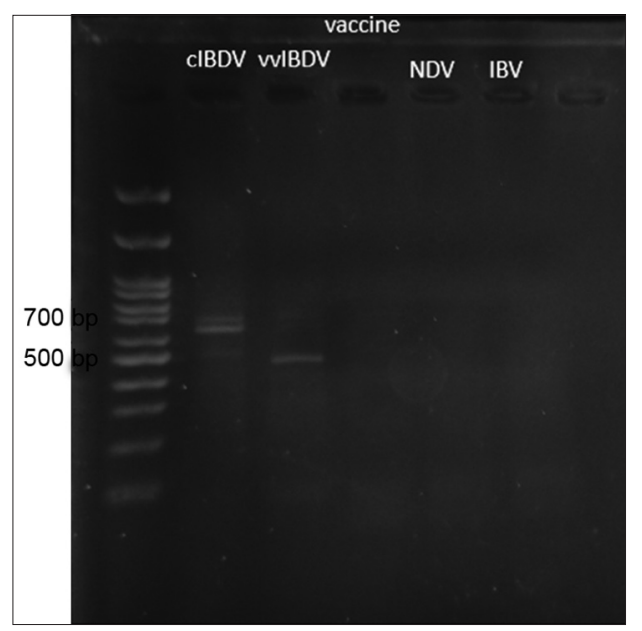

Figure-1: Result of multiplex reverse transcriptionpolymerase chain reaction showed a specific band of classic infectious bursal disease virus (BDV) at 700 base pairs and a specific band of very virulent infectious BDV at 500 base pairs. There was no specific band in other viruses.

vaccine development and diagnostic techniques. However, the new technologies usually require expensive equipment and materials. If problems are noticed on the farm, the farmer has to send the samples to a laboratory to differentiate the IBDV strain and consequently plan to adapt the vaccination program. Fast diagnostic results and strain identification will benefit the prevention and control program [11]. Nowadays, larger farms have developed diagnostic tools to serve their own farms and customer (the contact farms). Hence, less expensive and less complicated diagnostic methods are still advantageous.

The result of this study showed that at least two genogroups of IBDV (genogroup 1 [cIBDV] and genogroup 3 [vvIBDV]) were found circulating in Thailand. The whole-genome sequencing of four samples was performed to study the appropriate site to differentiate IBDV strains. Unfortunately, only partial sequences of both segments A and B were successfully determined. Based on the homology result of segment A, samples 1 and 2 were classified as genogroup 1 because they were most similar to STC strain isolated in the United States [12]. Samples 3 and 4 were classified as genogroup 3 as they were highly similar to the isolates from this genogroup. Moreover, they were highly similar to isolate UPM766/2018, which was reported in Malaysia [13] and HLJ-0504, which was reported in China [14]. There were no other variant IBDV strains found in this study. Interestingly, vaIBDV was recently reported in Malaysia and China [13,15]. Therefore, considering geographic territory, the variant strain may already have been circulating in Thailand. This result indicates that surveillance of IBDV must be performed continuously. Unfortunately, Jackwood and SommerWagner (2007) are the only authors to report the nucleotide sequences of IBDV in Thailand.

The next part of the study was to develop the RFLP technique or RT-PCR-RFLP and multiplex RT-PCR. Although the whole genome sequence was incomplete, the nucleotide sequence of cIBDV and vvIBDV was highly similar in both segment A and segment B (95.21\%). The point mutations were found throughout each segment, but only 1-2 base pairs of each point were different. Therefore, the restriction enzyme and primer for multiplex RT-PCR were difficult to develop. In our study, the RT-PCR-RFLP failed to differentiate cIBDV and vvIBDV. The result showed the same band at 400 base pairs, which meant that the selected restriction enzyme could not cut both cIBDV and vvIBDV samples. Therefore, if the whole genome sequence is completed, a longer part of the sequence will be selected and a more appropriate enzyme can be chosen; this may allow the RT-PCR-RFLP to differentiate the IBDV strains.

In this study, the RT-PCR-RFLP method could not be developed. However, the multiplex RT-PCR showed good results. It was able to differentiate cIBDV from vvIBDV, showing specific bands at 700 base pairs and 500 base pairs, respectively. The primers were able to be placed in the same reaction and used the same annealing temperature. In addition, the multiplex RT-PCR was less time-consuming, less complicated, and cheaper than the RT-PCR-RFLP technique. Therefore, multiplex RT-PCR may be suitable for farmers to use on the farm.

\section{Conclusion}

Although multiplex RT-PCR is not a new method, it is easy to apply in small laboratories and does not require high skill or expensive equipment. However, further study of the IBDV strains circulating in Thailand should be performed with more number of samples to benefit the prevention and control of IBDV.

\section{Authors' Contributions}

NC: Collected the bursa of Fabricius from farms A, C, D, E, H, K, M, N, O, and P, designed experiment, processed all the laboratory work, concluded and wrote the manuscript and approved the final manuscript.

\section{Acknowledgments}

This study was supported by Thailand Research Fund (Grant no. MRG6080197). The author is thankful to Prof. Dr. Jiroj Sasipreeyajan for providing the bursa of Fabricius from farms B, F, G, I, J, and L.

\section{Competing Interests}

The author declares that she has no competing interests. 


\section{Publisher's Note}

Veterinary World remains neutral with regard to jurisdictional claims in published institutional affiliation.

\section{References}

1. Eterradossi, N. and Saif, Y.M. (2020) Infectious bursal disease. In: Swayne, D.E., editor. Diseases of Poultry. $14^{\text {th }}$ ed. Wiley and Sons, Inc., New York, United States. p257-283.

2. Müller, H., Islam, M.R. and Raue, R. (2003) Research on infectious bursal disease-the past, the present and the future. Vet. Microbiol., 97(1-2): 153-165.

3. van den Berg, T.P. (2000) Acute infectious bursal disease in poultry: A review. Avian Pathol., 29(3): 175-194.

4. Wu, C.C., Rubinelli, P. and Lin, T.L. (2007) Molecular detection and differentiation of infectious bursal disease virus. Avian Dis., 51(2): 515-526.

5. Tomás, G., Hernándeza, M., Marandinoa, A., Techeraa, C., Greccoa, S., Hernándeza, D., Bandab, A., Panzeraa, Y. and Péreza, R. (2017) Development of an RT-qPCR assay for the specific detection of a distinct genetic lineage of the infectious bursal disease virus. Avian Pathol., 46(2): 150-156.

6. Michel, L.O. and Jackwood, D.J. (2017) Classification of infectious bursal disease virus into genogroups. Arch Virol., 162(12): 3661-3670.

7. Jackwood, D.J. and Sommer-Wagner, S. (2007) Genetic characteristics of infectious bursal disease viruses from four continents. Virology, 365(2): 369-375.

8. Jackwood, D.J. and Sommer, S.E. (1997) Restriction fragment length polymorphisms in the VP2 gene of infectious bursal disease viruses. Avian Dis., 41(3): 627-637.

9. Tamura, K., Nei, M. and Kumar, S. (2004) Prospects for inferring very large phylogenies by using the neighbor-joining method. Proc. Natl. Acad. Sci. U. S. A., 101(30): 11030-11035.

10. Kumar, S., Stecher, G., Li, M., Knyaz, C. and Tamura, K. (2018) MEGA X: Molecular evolutionary genetics analysis across computing platforms. Mol. Biol. Evol., 35(6): $1547-1549$

11. Jackwood, D.J. (2004) Recent trends in the molecular diagnosis of infectious bursal disease virus. Anim. Health Res. Rev., 5(2): 313-316.

12. Kibenge, F.S.B., Jackwood, D.J. and Mercado, C.C. (1990) Nucleotide sequence analysis of genome segment A of infectious bursal disease virus. J. Gen. Virol., 71(3): 569-577.

13. Aliyu, H.B., Hair-Bejo, M., Omar, A.R. and Ideris, A. (2021) Genetic diversity of recent infectious bursal disease viruses isolated from vaccinated poultry flocks in Malaysia. Front. Vet Sci., 8,1643976.

14. Li, K., Courtillon, C., Guionie, O., Allée, C., Amelot, M., Qi, X., Gao, Y., Wang, X. and Eterradossi, N. (2015) Genetic, antigenic and pathogenic characterization of four infectious bursal disease virus isolates from China suggests continued evolution of very virulent viruses. Infect. Genet. Evol., 301: 120-127.

15. Fan, L., Wu, T., Hussain, A., Gao, Y., Zeng, X., Wang, Y., Gao, L., Li, K., Wang, Y., Liu, C., Cui, H., Pan, Q., Zhang, Y., Liu, Y., He, H., Wang, X. and Qi, X. (2019) Novel variant strains of infectious bursal disease virus isolated in China. Vet. Microbiol., 230(1): 212-220.

$* * * * * * * *$ 